\author{
(online) $=$ ISSN $2285-3642$ \\ ISSN-L = $2285-3642$ \\ Journal of Economic Development, Environment and People \\ Volume 8, Issue 3, 2019 \\ URL: http://jedep.spiruharet.ro \\ e-mail: office jedep@spiruharet.ro
}

\title{
The Chief Digital Officer - Savior for the Digitalization in German Banks?
}

\author{
${ }^{1}$ Carsten Giebe, PhD Candidate \\ ${ }^{2}$ Kaposvár University - Doctoral School Management and Organizational Sciences
}

\begin{abstract}
Digitalization is changing processes in the German banking market. These changes pose significant challenges for companies. Many German banks could miss the connection in the age of digital transformation. They are forced to digitize processes due to low yields, as new players in the market (FinTechs) could shed up to $40 \%$ of sales and up to $60 \%$ of profits from traditional banking. How to deal with digitalization has been discussed widely. One idea that has been promoted and implemented, was installing a Chief Digital Officer along with the Chief Information Officer / Head of IT. Among the 2,500 largest publicly listed companies worldwide, 160 CDOs have been hired in 2016, 124 in 2017 and 54 in 2018, according to a 2019 study by PWC's strategy\&. Numbers have gone down and it is in question whether and how long the position of a CDO will be crucial for business success. Only 7\% of German banks currently employ a CDO. Creating the role of a CDO alone will not be a measure for success in organizations, as long as it is not accompanied with a suitable digitalization strategy and a change management process that effectively highlights and persuades all of the organization stakeholders of the benefits.
\end{abstract}

Keywords: Change Management, Digital Transformation, Digitalization, CDO, Chief Digital Officer, German banks

JEL Codes: G21, M54

How to cite: GIEBE, C. (2019). The Chief Digital Officer - Savior for the Digitalization in German Banks. Journal of Economic Development, Environment and People, 8(3), 6-15. doi:http://dx.doi.org/10.26458/jedep.v8i3.633

\section{Introduction}

The use and integration of new digital technologies is one of the biggest challenges facing businesses today. No company can defend itself against the effects of digital transformation. Digital transformation describes the integration of digital technologies into business processes (Liu, Chen, Chou, 2011). The potential is market-changing and often greater than sales channels, business processes or supply chains. Complete business models are often redesigned. As a result, digital transformation has become a very high priority at management level (Hess, Matt, Benlian \& Wiesböck, 2016).

Digital transformation can be considered as a paradigm shift. The concept of "paradigm shift" was coined by US historian Thomas Kuhn in his work "The Structure of Scientific Revolution" in 1962. According to Kuhn, science is not a continuous, piecemeal expansion of knowledge - it is shaped by occasional revolutions. These revolutions each reveal a new "paradigm", a system of innovation that shapes science at a particular time. New paradigms emerge when the weaknesses or contradictions in "normal science" pile up (Kugler, 2012). Over the past decade, the influence of digital technologies has had a huge impact on 


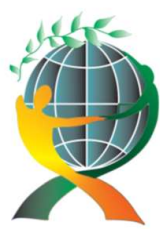

\author{
(online) $=$ ISSN $2285-3642$ \\ ISSN-L = $2285-3642$ \\ Journal of Economic Development, Environment and People \\ Volume 8, Issue 3, 2019 \\ URL: http://jedep.spiruharet.ro \\ e-mail: office jedep@spiruharet.ro
}

businesses and people's daily lives. Digital devices and new digital technologies have swept the market and it has become unthinkable to halt or slow this process of rapid innovation due to the many advantages and positive effects they have created.

The banking sector is one that is largely impacted by this paradigm shift. Traditional banking is experiencing negative consequences as many lack viable digital strategies. Newly created financial technology (FinTech) companies mainly offer a wide range of services with added value for banks. Their focus is on improving service quality through the use of information technology (IT) applications (Gai, Qiu \& Sun, 2018). The term FinTech is made up of the initial syllables of financial services and technology. They are considered to be one of the most important innovations by the financial industry, evolving rapidly. FinTech is the industry in which financial services are transformed using technology. This is partly due to the sharing of information on information technology. FinTechs promise a reorganisation of the financial sector as they can improve the quality of financial services. Technological innovations in the areas of big data, data analysis and mobile devices allow FinTech start-ups to support traditional banks with personalized services (Lee \& Shin, 2018). Due to its explosiveness and topicality, digital transformation in the banking sector can be described as a paradigm shift for sure. Hence, businesses in the banking market need to think about how to effectively manage this transformation. One way to do so is the implementation of the role of a Chief Digital Officer within the managerial board.

\title{
1. Methodology and Research Question
}

Managers often lack a focus on the various options and elements that arise from digital transformation. Recent approaches to research show that there is a need for advice on certain aspects of digital transformation. However, research does not address a holistic approach to developing a digital, enterprisewide transformation strategy (Hess, Matt, Benlian, Wiesböck, 2016). Therefore my research question focuses on whether and to what extent a CDO can be the savior for the German banking sector in the age of digital transformation. An age that faces the challenge of optimally balancing the interaction between "man and machine", and an age that is more and more influenced by big data. The methodology consists of several months of literature research. I used the keywords: CDO, Chief Digital Officer, digitalization, digital transformation, German banks, and banking sector and retrieved the literature from Google Scholar and Elsevier, newspapers, company websites and other web pages.

\section{Literature Review and Current State}

The search for suitable literature posed a significant challenge, because the subject has not been clearly defined yet. Although, I researched various journals, articles in those journals did not deal with the German banking market in particular. For this reason, this paper has been supplemented with sources and studies 


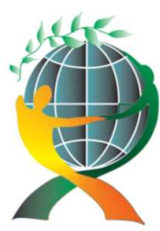

\author{
(online) $=$ ISSN $2285-3642$ \\ ISSN-L = $2285-3642$ \\ Journal of Economic Development, Environment and People \\ Volume 8, Issue 3, 2019 \\ URL: http://jedep.spiruharet.ro \\ e-mail: office jedep@spiruharet.ro
}

that are relevant to answering my research question and focus on the German market. On closer examination, no concrete CDO figures for the German banking market could be researched.

In the US and UK, for example, $90 \%$ of executives expect digital technologies to make a growing strategic contribution in the coming years. The question is no longer when companies will give digital transformation a high priority, but rather how (Hess, Matt, Benlian, Wiesböck, 2016). In many industries, from industry to science, a "digital change" can be observed along the various value chains. The activities of the companies are carried out with a growing amount of internal and external information. Companies also increasingly believe in information-based impulses to promote innovation, solve problems or improve processes (Kauffmann \& Weber, 2018). There are two perspectives in the age of digitization: on the one hand, the data-driven, on the other - the theoretical perspective. Focusing exclusively on data-driven analysis can help identify correlations but may not contribute to any scientific lasting knowledge. Hence, the theoretical perspective is not any less important. However, without the emphasis on the use of datadriven knowledge, opportunities may be missed and negatively impact businesses (Maass, Parsons, Purao, Storev \& Woo, 2018). A look at the banking sector shows that due to technological change and globalisation, financial markets have become more fragmented.

An important challenge for research is to unpack the existing massive collections of various data (big data) and use them profitably (Seddon, Currie, 2017). In recent years, big data has been seen as a major technological breakthrough. However, there is still a limited understanding of how organisations translate their potential into real economic and social value. It is an insight that companies need to constantly reorder their organizational models and work practices in order to reap the benefits of big data. (Günther, Mehrizi, Huysman \& Feldberg, 2017).

Many banks in Germany could miss the connection in the age of digital transformation. On the one hand, external influences such as customer behaviour, customer expectations, technological change, willingness to pay and product life cycles are gaining in importance. On the other hand, the internal expectation of employees, e.g. the acceptance of new technological solutions and processes happens rather slowly. According to a study by the management consultancy McKinsey, traditional banks could lose 29-35\% of revenue due to competition with FinTech businesses (Drummer, Jerenz, Siebelt \& Thaten, 2016). According to the study, German banks are forced to digitize processes due to low returns. As new players enter the market, they could lose as much as $40 \%$ of their sales and up to $60 \%$ of profits. FinTechs pose serious competitors in entire product areas in the banking sector. An example is giving loans or credits Auxmoney.de respectively smava.de or the current account area with N26.com are two players in the market attacking traditional banks in the credit sector. The difficult part of the digitalization challenge is the simplification of structures and processes and how to optimally face this challenge (Drummer, Jerenz, Siebelt, Thaten, 2016). There are always new players in the market who want to win customers from banks with a special service offering. These reach the customers on sales channels that have not even existed years ago. These include, for example, various social networks and chat bots. The challenge lies in the 


\author{
(online) $=$ ISSN $2285-3642$ \\ ISSN-L = $2285-3642$ \\ Journal of Economic Development, Environment and People \\ Volume 8, Issue 3, 2019 \\ URL: http://jedep.spiruharet.ro \\ e-mail: office jedep@spiruharet.ro
}

constantly changing lifestyles and needs of the customers (Giebe 2018), and therefore German banks need to keep up with the speed of this change. Hence, how can digitalization not only be seen as a CHANGE, but rather as a CHANCE for German banks? Thorsten Dirks, Chief Executive Officer of Telefónica Deutschland AG, said in an interview with the Süddeutsche Zeitung on October 16, 2016: "If you have a shit process and digitalize it, then you have a shit digital process." This quotation impressively describes the current challenges of digital transformation. Hence, the way to properly structure processes and digitize them is constantly being discussed. Amongst other factors, digitalization and competition from more innovative banking trends, can be seen as one reason for the decline in savings bank in the past 25 years. As depicted in the graph below, the amount of savings banks existent in Germany between 1993 and 2017 has almost halved. Numbers dropped steadily from around 780 to 400 in 2017.

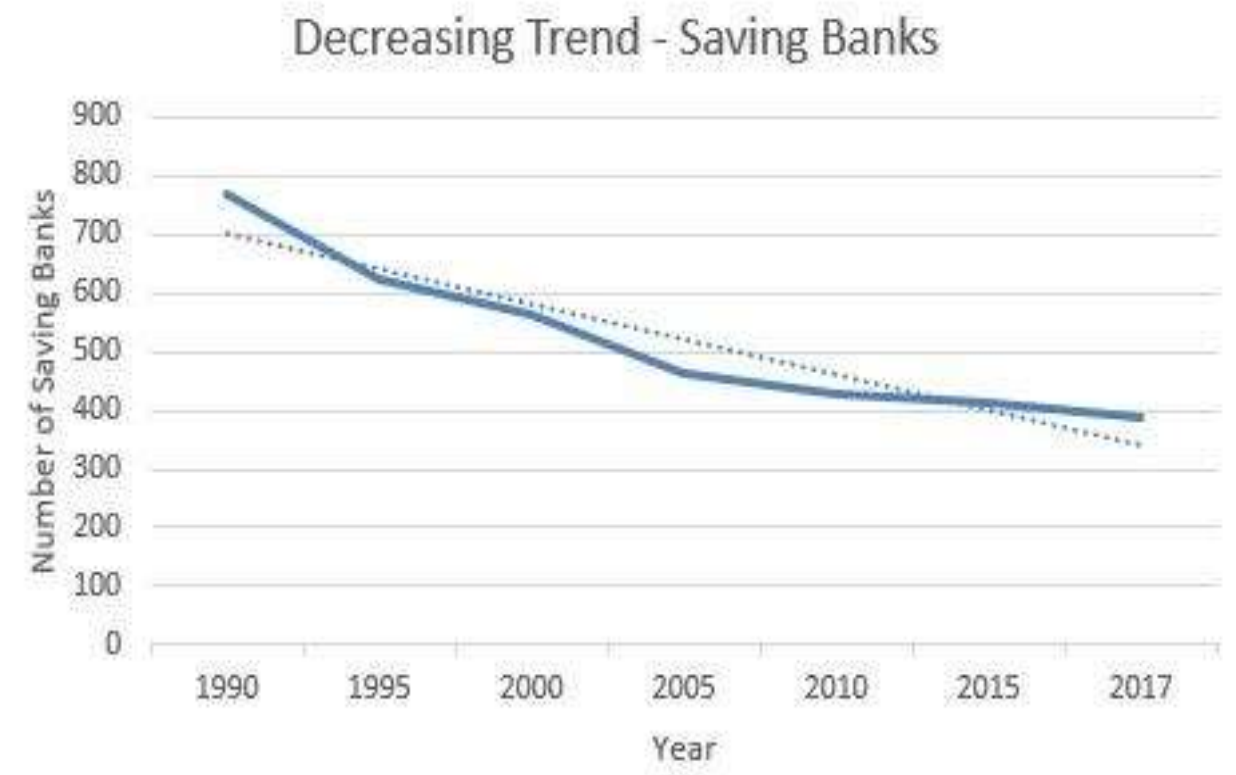

Fig. 1: The number of individual savings banks in Germany has almost halved in 25 years Source: 17.05.2018 Deutsche Bundesbank (German Central Bank)

\title{
3. Solution Approaches
}

A company's digital strategy can only add value if it pools resources and promotes investment. Many Chief Executive Officers (CEOs) are reluctant to define a digital strategy. However, the best digital strategies 


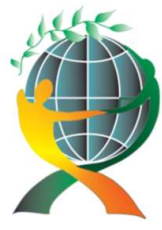

\author{
(online) $=$ ISSN $2285-3642$ \\ ISSN-L = $2285-3642$ \\ Journal of Economic Development, Environment and People \\ Volume 8, Issue 3, 2019 \\ URL: http://jedep.spiruharet.ro \\ e-mail: office jedep@spiruharet.ro
}

have guided operational decisions, and strategic decisions at the same time. An interesting finding is that the success with the chosen digital strategy also led to results that are linked to other strategies, for example a strategy to achieving customer loyalty (Sebastian, Ross, Beath, Mocker, Moloney, Fonstad, 2017).

One way to manage the organization effectively is to install a Chief Digital Officer (CDO). This position is being installed in companies to coordinate the digital transformation. Results of previously mentioned research show, that the execution and implementation of change processes is one of the central tasks of the CDO. Furthermore, it is necessary to observe the development of digital trends. A digital strategy must be developed and acted out across divisions as well. Maintaining networks and creating efficient structures are also considered to be tasks of a CDO. The CDO is designed to create fundamental innovations. And its activities are not limited to individual departments. Digital agendas should be anchored across the company. All this should be reflected in the task of interface coordination of the CDO (Walchshofer, Riedel, 2017). The CDO's current priority is to change the mindset within the top management team and among employees, before any specific digital projects can be initiated. New perspectives should be used and upcoming changes in the market should be presented by the CDO. Innovative solutions are key to facing future challenges and secure a profitable market share. Although the CDO operates in a separate entity, it works closely with various stakeholders, notably the internal communications department and client advisors (Singh, Hess, 2017). Looking at other industries, there are examples of CDO implementations from overseas, such as the US (Doonan, 2018). The latest study by PWC and strategy\& authored by Péladeau and Acker from March 2019 shows declining numbers of CDO implementations within the 2500 largest publicly listed companies compared to their prior study findings from 2016 and 2017. Distinctly new CDO position was only created in 54 companies, compared to 154 in 2017 and 160 in 2016. 60\% of CDOs were hired in 2015 and 2016 (strategy\&, 2017)

\title{
Proportion of companies with CDOs - a sector comparison
}

As depicted in the chart below from 2016, the use of CDOs in banks is currently at seven percent. Hence, only a few major banks have installed the CDO position (strategy\&, 2016). Communications, media, entertainment (13\%) and food, beverage, agriculture (11\%) businesses, were in the top, but even in these industries, the figures are rather low. Hence, the position of the CDO is either not widespread enough yet and may increase in the coming years or tasks around digitalization might be integrated in other organizational functions. 

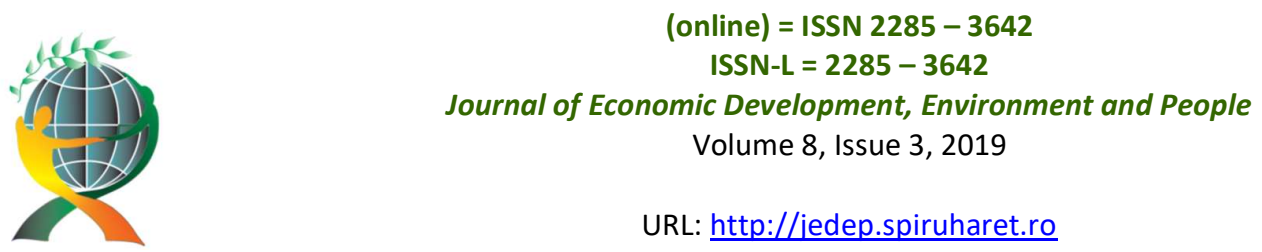

URL: http://jedep.spiruharet.ro e-mail: office jedep@spiruharet.ro

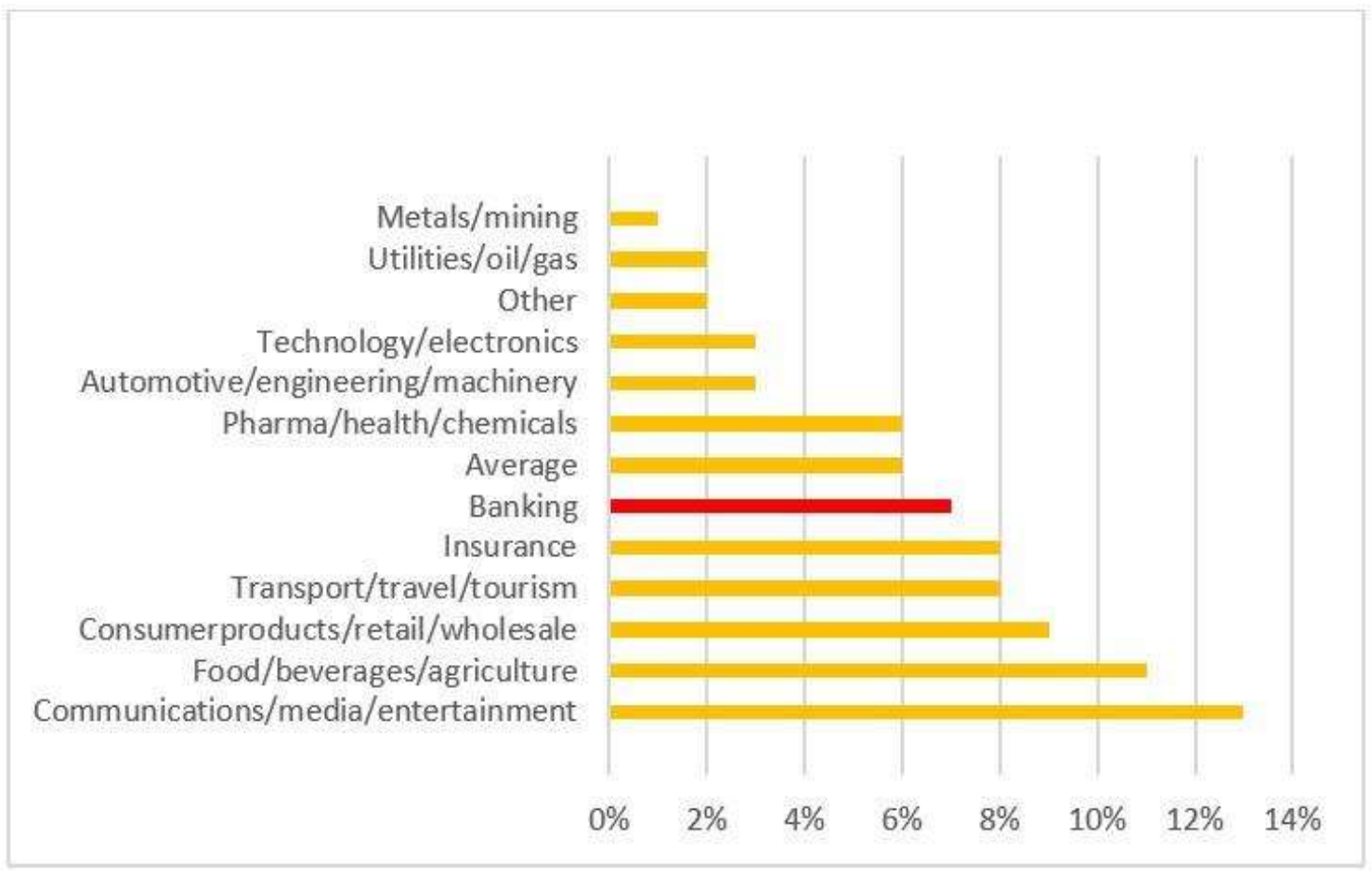

Fig. 2: The share of banks with a Chief Digital Officer is just above the average of all sectors

Source: https://www.der-bank-blog.de/chief-digital-officer-und-change/studien/digitalisierung/21099/

\section{Appraisal}

The question is whether a CDO can solve the problem of the current unstructured or lacking digital processes consistently? Due to the novelty of this management position, there is no clear definition of the requirements profile of the CDO. So it is not always clearly defined which tasks and activities the CDO has. The question of whether the CDO is a permanent or a temporary position in the company could not be answered clearly during my research either. Also, the perceptions of the tasks are similar to those of a Chief Information Officer ( $\mathrm{ClO}$ ) which are currently installed in German banks. It is therefore important to work out the differences and the similarities in order to avoid a competency overlap between the two functions. Solutions that have been developed on the basis of recognized empirical research methods do not exists yet (Kawohl, Schneider, 2017). What are the tasks of the CDO and what kind of results are expected from this position? In general, CDOs help their companies make the most of digital technologies. They are constantly involved in the development of digital skills. The CDO of an organization is also responsible for challenging the existing business model. To meet the requirements, the CDO must be able to experiment 


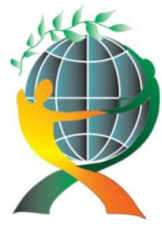

\author{
(online) $=$ ISSN $2285-3642$ \\ ISSN-L = $2285-3642$ \\ Journal of Economic Development, Environment and People \\ Volume 8, Issue 3, 2019 \\ URL: http://jedep.spiruharet.ro \\ e-mail: office jedep@spiruharet.ro
}

with and apply many digital technologies. However, these emerging areas are steadily increasing (Tumbas, Berente, Brocke, 2017). There are organizations with IT departments that do much of what CDOs do. These include, for example, innovations with digital technologies. Therefore, CDOs have to delineate their responsibilities. For this reason, $\mathrm{CDO}$ s should focus to a high degree on their identification in the company (Tumbas, Berente, Brocke, 2018). The CDO must be incorporated at senior management level. He/ She is to connect the external and internal perspectives in the digital transformation. This means being able to connect the internal processes with customer wishes. In addition to technological knowledge, the CDO must also have an understanding of the customers (Zisler, Mohr, Strahl \& Dowling, 2016). Regardless of the position of the $C D O$, digital transformation should be considered as a change management process. Changes in organizations, processes and technologies have a large impact on human capital. Change management involves the development and implementation of positive and goal-oriented strategies. Almost every major intervention in a company can be supported by change management. The resulting benefit should be a smooth change process that results from less resistance from employees. Other possible positive side effects are resource cuts and the acceptance of the actual change. However, the prerequisites are a clear vision and measurable goals of the planned project. Meticulous planning and preparation are fundamental. Significantly, these processes should be supported by management. In addition to goal-oriented communication in support of change management, the development of "quick wins", immediate positive effects for each individual employee, is essential (Schawel, Billing, 2018).

\title{
5. Further Aspects
}

Human Resources focus on training and personnel development. But talent management, performance management and compensation management also play an important role in implementing the digitalization strategy. Staff should play a more active role in the age of digitalization. This is the only way to ensure that human capital is competent and qualified. In this way, the need for digitalization can be met both now and in the future. It is important to coordinate all human resources activities. If this is the case, a company's digitization strategy can be achieved (Fenech, Baguant, Ivanov, 2019).

In addition to the described organizational measures, external business coaching for executives is a very effective means of digital transformation. The goal of this process-oriented form of counselling is to accompany a manger in the digital transformation process by giving advice and support in a coaching relationship. In doing so, it is important to support them to be sustainably successful and to experience their work as fulfilling. This has been recently identified as part of a study during the last financial crisis to measure effects on stress, resilience and performance. The research results showed that the coaching program helped managers to improve their performance. Coaching digitalization can therefore be given as a managerial recommendation (David, Ionicoiu, Imbăruş, Sava, 2016).

Concerning the need for qualification, the demands on the social skills of the workforce are increasing again in the digital age. Ultimately, it requires employees with strong communication skills and a high level of cooperation. By contrast, the long-term professional experience with its positive benefits, such as enhanced soft- and communication skills, is called into question because even successful start-ups are 


\author{
(online) $=$ ISSN $2285-3642$ \\ ISSN-L = $2285-3642$ \\ Journal of Economic Development, Environment and People \\ Volume 8, Issue 3, 2019 \\ URL: http://jedep.spiruharet.ro \\ e-mail: office jedep@spiruharet.ro
}

founded primarily by young people without extensive professional experience (Hammermann, Stettes, 2016). Therefore, it could be beneficial for the banking sector to allow young professionals into roles that require not only technical capabilities but also advanced social skills.

\title{
6. Conclusion
}

Taking a look at the banking industry, a need for action can be identified quickly. This is largely due to an environment that prevails in this sector, in which rapid environmental changes are combined with strict IT governance requirements. Banks face increasingly stringent regulatory and complex requirements in order to limit business risks. To comply with these requirements, robust governance and complex IT infrastructures must be ensured (Gregory, Kaganer, Henfridsson \& Ruch, 2018). Therefore, it is important to align the company's capabilities with new technologies, whereas the emphasis should be on the internal processes of companies. Furthermore, the way in which they are used and how they will develop. Competitive advantage depends on which strategic assets banks can serve and how to use these assets in a changing market. This could include the implementation of a CDO in the organization (Teece, Pisano, Shuen, 1997). As there is massive pressure on retail banks, the situation offers exceptional opportunities for traditional players, new entrants and new companies. An innovation in the customer experience is essential. The optimization of processes is a prerequisite for economic success. Traditional banks must become digital banks to a great extent in order to take advantage of the opportunities of the digital economy (Ilie, Popescu, lacob, 2017). Hence, there is a lot of dynamism in the market, but a stringent digital strategy is missing. Along with this however, stands the assumption that a CDO in the traditional banking sector may not necessarily have to be the perfect way of successfully managing digital transformation. In fact, Péladeau and Acker (2019) hypothesize that "as transformation becomes part of the core business, the next step will be for the CDO to disappear. Digital transformation will become the responsibility of every member of the executive team." So, can the CDO be considered the salvation giver for the digitali7ation of banks in Germany? It is crucial that the responsibility for the success of the digital transformation is not limited to the person of the CDO alone because the mere installing of a CDO does not solve the challenges of digitalization. Due to the low occupation of a CDO - seven percent in 2016 in banks, one has to assume that the CDO will not be a saviour at the moment for German banks. However, as the trend of implementing this position is increasing, this is just a fixed number representing one year in time. A CDO philosophy is currently developing in Germany. The bottom line is that digitalization is not a project that ends sometime. Digitalization does not belong in a separate area. Digitalization is a process that accompanies banks from now on and needs intelligent implementation strategies. Digitalization will become a natural part of the daily work in the organization. From the cleaning personnel to the CEO, every employee has to demonstrate and develop digital skills. How successful a change management process will be in terms of digitalization therefore depends largely on the willingness of banks in Germany to make a 


\author{
(online) $=$ ISSN $2285-3642$ \\ ISSN-L = $2285-3642$ \\ Journal of Economic Development, Environment and People \\ Volume 8, Issue 3, 2019 \\ URL: http://jedep.spiruharet.ro \\ e-mail: office jedep@spiruharet.ro
}

change. This can only be achieved by clarifying this problem, raising awareness and developing strategies that involve and enable all employees.

\title{
7. References
}

[1] https://blog.telefonica.de/2016/10/ceo-thorsten-dirks-im-sz-interview-ich-habe-heute-kein-festes-buero-mehr/ [Access June 2019]

[2] strategy\& (2016) https://www.der-bank-blog.de/chief-digital-officer-und-change/studien/digitalisierung/21099/ [Access June 2019]

[3] David, O. A., Ionicioiu, I., Imbăruş, A. C., \& Sava, F. A. (2016). Coaching banking managers through the financial crisis: Effects on stress, resilience, and performance. Journal of rational-emotive \& cognitive-behaviour therapy, 34(4), 267-281.

[4] Doonan, M. (2018). So you've just hired a killer chief digital officer-now what? Strategic HR Review, 17(1), 17-22.

[5] Drummer, D., Jerenz, A., Siebelt, P., \& Thaten, M. (2016). FinTech - Challenges and Opportunities How digitization is transforming the financial sector. McKinsey \& Company, (May), 1-7. Retrieved from http://www.mckinsey.com/industries/financial-services/our-insights/fintech-challenges-and-opportunities [Access June 2019]

[6] Fenech, R., Baguant, P., \& Ivanov, D. (2019). THE CHANGING ROLE OF HUMAN RESOURCE MANAGEMENT IN AN ERA OF DIGITAL TRANSFORMATION. International Journal of Entrepreneurship, 22(2).

[7] Gai, K., Qiu, M., \& Sun, X. (2018). A survey on FinTech. Journal of Network and Computer Applications, 103, 262273.

[8] Giebe, C. (2018). Net Promoter Score (NPS) als qualitatives Steuerungsinstrument in der Finanzdienstleistungsbranche (21-22).

[9] Gregory, R. W., Kaganer, E., Henfridsson, O., \& Ruch, T. J. (2018). IT Consumerization and the Transformation of IT Governance. MIS Quarterly, 42(4), 1225-1253.

[10] Günther, W. A., Mehrizi, M. H. R., Huysman, M., \& Feldberg, F. (2017). Debating big data: A literature review on realizing value from big data. The Journal of Strategic Information Systems, 26(3), 191-209.

[11] Hammermann, Andrea; Stettes, Oliver (2016): Qualifikationsbedarf und Qualifizierung: Anforderung im Zeichen der Digitalisierung, IW policy paper, No. 3/2016.

[12] Hess, T., Matt, C., Benlian, A., \& Wiesböck, F. (2016). Options for formulating a digital transformation strategy. MIS Quarterly Executive, 15(2).

[13] Ilie, O.-M.., Popescu, C., \& lacob, S. E. (2017). Transforming the Banking Organization in the Context of Digital Economy. Proceedings RCE 2017, 284-292.

[14] Kauffman, R. J., \& Weber, T. A. (2018). The Digital Transformation of Vertical Organizational Relationships.

[15] Kawohl J., Schneider, P. (2017) Wer braucht schon einen Chief Digital Officer? Eine Analyse der DAX- und MDAX Konzerne. Hochschule für Technik und Wirtschaft Berlin/ Professur für Strategisches Management. https://docs.wixstatic.com/ugd/63eb59_998b700c3f124aac8cbc1100cf5444bb.pdf

[16] Kugler, Martin (16.12.2012), „Die Presse", Print-Ausgabe 


\author{
(online) $=$ ISSN $2285-3642$ \\ ISSN-L = 2285 - 3642 \\ Journal of Economic Development, Environment and People \\ Volume 8, Issue 3, 2019 \\ URL: http://jedep.spiruharet.ro \\ e-mail: office jedep@spiruharet.ro
}

[17] Lee, I., \& Shin, Y. J. (2018). Fintech: Ecosystem, business models, investment decisions, and challenges. Business Horizons, 61(1), 35-46.

[18] Liu, D. Y., Chen, S. W., \& Chou, T. C. (2011). Resource fit in digital transformation: Lessons learned from the CBC Bank global e-banking project. Management Decision, 49(10), 1728-1742.

[19] Maass, W., Parsons, J., Purao, S., Storey, V. C., \& Woo, C. (2018). Data-driven meets theory-driven research in the era of big data: opportunities and challenges for information systems research. Journal of the Association for Information Systems, 19(12), 1253-1273.

[20] Péladeau, P., Acker, O. (2019). Have we reached "peak" chief digital officer? Strategy + business. March 26, 2019.Retrieved from: https://www.strategy-business.com/blog/Have-we-reached-peak-chief-digitalofficer?gko=2443a [Accessed: July 7, 2019].

[21] Schawel C., Billing F. (2018) Change Management. In: Top 100 Management Tools. Springer Gabler, Wiesbaden, https://doi.org/10.1007/978-3-658-18917-4_19

[22] Sebastian, I., Ross, J., Beath, C., Mocker, M., Moloney, K., \& Fonstad, N. (2017). How big old companies navigate digital transformation.

[23] Seddon, J. J., \& Currie, W. L. (2017). A model for unpacking big data analytics in high-frequency trading. Journal of Business Research, 70, 300-307.

[24] Singh, A., \& Hess, T. (2017). How Chief Digital Officers Promote the Digital Transformation of their Companies. MIS Quarterly Executive, 16(1).

[25] Teece, D. J., Pisano, G., \& Shuen, A. (1997). Dynamic capabilities and strategic management. Strategic management journal, 18(7), 509-533.

[26] Tumbas, S., Berente, N., \& vom Brocke, J. (2018). Digital innovation and institutional entrepreneurship: Chief Digital Officer perspectives of their emerging role. Journal of Information Technology, 33(3), 188-202.

[27] Tumbas, S., Berente, N., \& vom Brocke, J. (2017). Three Types of Chief Digital Officers and the Reasons Organizations Adopt the Role. MIS Quarterly Executive, 16(2).

[28] Walchshofer, M., Riedel, R. (2017). Der Chief Digital Officer (CDO): Eine empirische Untersuchung. HMD Praxis der Wirtschaftsinformatik, June 2017, Volume 54, Issue 3, pp 324-337, (doi: 10.1365/s40702-017-0320-7)

[29] Zisler, K., Mohr, N., Strahl, A., \& Dowling, M. (2016). Chief Digital Officer: Enabler der digitalen Transformation. Zeitschrift Führung+ Organisation, 85(2), 76-83. 